\title{
Obiektowe podejście w modelowaniu procesów pomiarowych w badaniach pojazdów szynowych
}

\begin{abstract}
$W$ artykule przedstawiono zastosowanie wybranych formalizmów $w$ modelowaniu procesów pomiarowych. Przedstawiono diagramy UML dla przykładowych elementów modelu procesu pomiarowego. Podkreślono korzyści wynikajace z zastosowania modelu obiektowego.
\end{abstract}

\section{Wprowadzenie}

Proces pomiarowy jest realizowany w celu wyznaczenia wartości wielkości reprezentujących badany układ. Modelowanie procesu pomiarowego ma coraz większe znaczenie jako etap przygotowawczy do projektowania systemu pomiarowego. W modelach procesów pomiarowych stosowane są formalizmy matematyczne na różnym poziomie abstrakcji: model lingwistyczny, model $\mathrm{w}$ postaci diagramów funkcjonalnych $[2,3]$, model topologiczny [5]. Epistemologiczne aspekty modelowania procesu pomiarowego przedstawiono $\mathrm{W}$ [2].

Ze względu na postęp w zakresie badań eksperymentalnych, wynikający $\mathrm{z}$ zastosowania nowoczesnych układów sterowania i regulacji oraz wprowadzania $\mathrm{w}$ szerokim zakresie techniki komputerowej, zaistniała konieczność integracji działań specjalistów z wielu dziedzin $\mathrm{w}$ procesie projektowania systemów pomiarowych. W tym celu w modelowaniu procesu pomiarowego zaproponowano podejście obiektowe $[4,6]$.

\section{Modelowanie procesu pomiarowego za pomocą odwzorowań}

Uogólniony model procesu pomiarowego przedstawiono w postaci odwzorowania oznaczonego PP

$$
\mathrm{PP}: \mathrm{A} \rightarrow \mathrm{B}
$$

gdzie:

A - zbiór atrybutów reprezentujących badany układ i jego działanie $A=\left\{A_{1}, \ldots, A_{i}, \ldots\right\}$,

$\mathrm{B}$ - zbiór symboli reprezentujący zmierzone wartości $\mathrm{B}=\left\{\mathrm{B}_{1}, \ldots, \mathrm{B}_{\mathrm{j}}, \ldots\right\}$.

Pierwotną operacją w procesie pomiarowym jest wydzielenie badanego układu $\mathrm{z}$ otoczenia oraz wybór wielkości reprezentujących układ i jego działanie. W wyniku uzyskano zbiór $\mathrm{X}^{\mathrm{R}}$ przyjęty jako model rzeczywistego układu.

$$
X^{R}=\left\{X_{1}^{R}, \ldots, X_{r}^{R}, \ldots\right\}
$$

Wielkość $X_{r}^{\mathrm{R}}$ opisano strukturą algebraiczną:

$$
\mathrm{X}_{\mathrm{r}}^{\mathrm{R}}=\left\langle\left\{\mathrm{x}_{\mathrm{r} 1}, \ldots, \mathrm{x}_{\mathrm{ru}}\right\}, \Re^{\mathrm{R}}\right\rangle
$$

gdzie:

$$
\begin{aligned}
& \mathrm{X}_{\mathrm{r} 1}, \ldots, \mathrm{x}_{\mathrm{ru}}-\text { wartości atrybutu } \mathrm{X}_{\mathrm{r}}^{\mathrm{R}}, \\
& \mathfrak{R}^{\mathrm{R}} \text { - relacja w zbiorze } \mathrm{X}_{\mathrm{r}}^{\mathrm{R}} .
\end{aligned}
$$

Na zbiorze wielkości $X^{R}$ przeprowadzono operację związaną $\mathrm{z}$ wyznaczaniem wielkości bezpośrednio mierzalnych, które zapisano w postaci zbioru $\mathrm{X}^{\mathrm{M}}$.

$$
\mathrm{X}^{\mathrm{M}}=\left\{\mathrm{X}_{1}^{\mathrm{M}}, \ldots, \mathrm{X}_{\mathrm{m}}^{\mathrm{M}}, \ldots\right\}
$$

Wielkość $\mathrm{X}_{\mathrm{m}}^{\mathrm{M}}$ opisano strukturą algebraiczną:

$$
\mathrm{X}_{\mathrm{m}}^{\mathrm{M}}=\left\langle\left\{\mathrm{x}_{\mathrm{m} 1}, \ldots, \mathrm{x}_{\mathrm{mv}}\right\}, \mathfrak{R}^{\mathrm{M}}\right\rangle
$$

gdzie:

$$
\begin{aligned}
& \mathrm{x}_{\mathrm{m} 1}, \ldots, \mathrm{x}_{\mathrm{mv}}-\text { wartości atrybutu } \mathrm{X}_{\mathrm{m}}^{\mathrm{M}}, \\
& \mathfrak{R}^{\mathrm{M}} \text { - relacja w zbiorze } \mathrm{X}_{\mathrm{m}}^{\mathrm{M}} .
\end{aligned}
$$

Wielkościom mierzalnym $\mathrm{X}^{\mathrm{M}}$ przypisano zbiór czujników pomiarowych, których wyjścia zapisano zbiorem $X^{\mathrm{C}}$.

$$
X^{C}=\left\{X_{1}^{C}, \ldots, X_{c}^{C}, \ldots\right\}
$$

Wielkość $\mathrm{X}_{\mathrm{c}}^{\mathrm{C}}$ opisano strukturą algebraiczną:

$$
\mathrm{X}_{\mathrm{c}}^{\mathrm{C}}=\left\langle\left\{\mathrm{x}_{\mathrm{c} 1}, \ldots, \mathrm{x}_{\mathrm{cw}}\right\}, \mathfrak{R}^{\mathrm{C}}\right\rangle
$$

gdzie:

$$
\begin{aligned}
& \mathrm{X}_{\mathrm{c} 1}, \ldots, \mathrm{X}_{\mathrm{cw}}-\text { wartości atrybutu } \mathrm{X}_{\mathrm{c}}^{\mathrm{C}}, \\
& \mathfrak{R}^{\mathrm{C}} \text { - relacja w zbiorze } \mathrm{X}_{\mathrm{c}}^{\mathrm{C}} .
\end{aligned}
$$

Dla przypadku, gdy w układzie pomiarowym zastosowano przetwornik, wyjściom z przetwornika przypisano zbiór $\mathrm{X}^{\mathrm{P}}$. 


$$
X^{P}=\left\{X_{1}^{P}, \ldots, X_{p}^{P}, \ldots\right\}
$$

Wielkość $X_{p}^{P}$ opisano strukturą algebraiczną:

$$
\mathrm{X}_{\mathrm{p}}^{\mathrm{P}}=\left\langle\left\{\mathrm{x}_{\mathrm{p} 1}, \ldots, \mathrm{x}_{\mathrm{px}}\right\}, \mathfrak{R}^{\mathrm{P}}\right\rangle
$$

gdzie:

$$
\begin{aligned}
& \mathrm{X}_{\mathrm{p} 1}, \ldots, \mathrm{x}_{\mathrm{px}}-\text { wartości atrybutu } \mathrm{X}_{\mathrm{p}}^{\mathrm{P}}, \\
& \mathfrak{R}^{\mathrm{P}} \text { - relacja w zbiorze } \mathrm{X}_{\mathrm{p}}^{\mathrm{P}} .
\end{aligned}
$$

Wielkości uzyskane z przetwornika poddano przetwarzaniu za pomocą odpowiednich procedur otrzymując zbiór $\mathrm{X}^{\mathrm{S}}$.

$$
\mathrm{X}^{\mathrm{S}}=\left\{\mathrm{X}_{1}^{\mathrm{S}}, \ldots, \mathrm{X}_{\mathrm{s}}^{\mathrm{S}}, \ldots\right\}
$$

Wielkość $\mathrm{X}_{\mathrm{s}}^{\mathrm{S}}$ opisano strukturą algebraiczną:

$$
\mathrm{X}_{\mathrm{s}}^{\mathrm{s}}=\left\langle\left\{\mathrm{x}_{\mathrm{s} 1}, \ldots, \mathrm{x}_{\mathrm{sy}}\right\}, \mathfrak{R}^{\mathrm{S}}\right\rangle
$$

gdzie:

$$
\begin{aligned}
& \mathrm{X}_{\mathrm{s} 1}, \ldots, \mathrm{x}_{\mathrm{sy}}-\text { wartości atrybutu } \mathrm{X}_{\mathrm{s}}^{\mathrm{S}}, \\
& \mathfrak{R}^{\mathrm{S}} \text { - relacja w zbiorze } \mathrm{X}_{\mathrm{s}}^{\mathrm{S}} .
\end{aligned}
$$

W celu uzyskania oceny układu poddanego pomiarowi, wielkości opisane zbiorem $\mathrm{X}^{\mathrm{S}}$ odpowiednio przekształcono otrzymując zbiór $\mathrm{X}^{\mathrm{O}}$.

$$
\mathrm{X}^{\mathrm{R}} \stackrel{\alpha}{\longrightarrow} \mathrm{X}^{\mathrm{M}} \stackrel{\beta}{\longrightarrow} \mathrm{X}^{\mathrm{C}}
$$

gdzie:

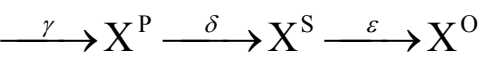

$\{\alpha\}$ - zbiór odwzorowań związanych z wyborem mierzalnych atrybutów,

$\{\beta\}$ - zbiór odwzorowań wynikających z wyboru czujników pomiarowych,

$\{\gamma\}$ - zbiór odwzorowań wynikających z wyboru przetworników pomiarowych,

$\{\delta\}$ - zbiór odwzorowań związanych z wyborem procedur przetwarzania,

$\{\varepsilon\}$ - zbiór odwzorowań związanych z wyborem procedur oceniania.

Zbiór wariantów modeli procesu pomiarowego przedstawiono jako iloczyn kartezjański:

$$
\begin{gathered}
\mathrm{X}^{\mathrm{R}} \times\{\alpha\} \times \mathrm{X}^{\mathrm{M}} \times\{\beta\} \times \mathrm{X}^{\mathrm{C}} \\
\times\{\gamma\} \times \mathrm{X}^{\mathrm{P}} \times\{\delta\} \times \mathrm{X}^{\mathrm{S}} \times\{\varepsilon\} \times \mathrm{X}^{\mathrm{O}}
\end{gathered}
$$

\section{Funkcjonalne ujęcie procesu pomiarowego}

Systemy pomiarowe są modelowane zwykle za pomocą modeli funkcjonalnych. Architektura takiego modelu reprezentowana jest blokami funkcjonalnymi charakteryzowanymi związkami między wyjściem a wejściem w postaci tak zwanej funkcji przejścia (rys. 1):

- blok czujnika lub przetwornika,

- blok funkcjonalnego przetwarzania sygnałów,

- $\quad$ blok interfejsu graficznego użytkownika.

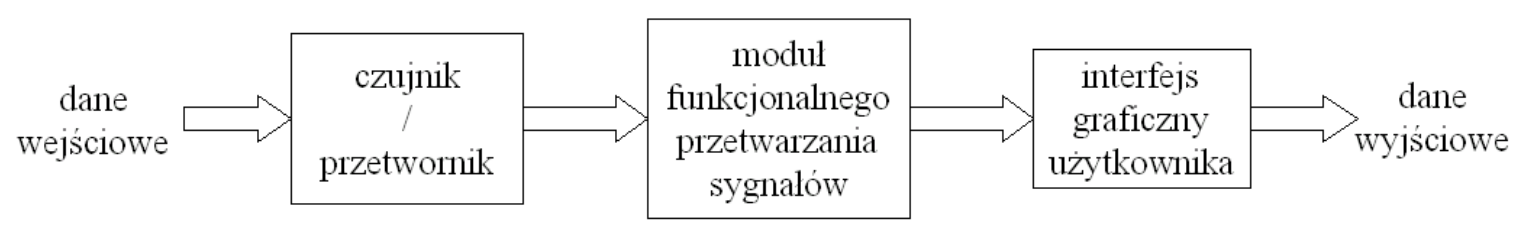

Rys. 1. Model procesu pomiarowego w ujęciu funkcjonalnym

$$
\mathrm{X}^{\mathrm{O}}=\left\{\mathrm{X}_{1}^{\mathrm{O}}, \ldots, \mathrm{X}_{\mathrm{o}}^{\mathrm{O}}, \ldots\right\}
$$

Wielkość $\mathrm{X}_{\mathrm{o}}^{\mathrm{O}}$ opisano strukturą algebraiczną:

$$
\mathrm{X}_{\mathrm{o}}^{\mathrm{O}}=\left\langle\left\{\mathrm{x}_{\mathrm{o} 1}, \ldots, \mathrm{x}_{\mathrm{oz}}\right\}, \mathfrak{R}^{\mathrm{O}}\right\rangle
$$

gdzie:

$$
\begin{aligned}
& \mathrm{x}_{\mathrm{o} 1}, \ldots, \mathrm{x}_{\mathrm{oz}}-\text { wartości atrybutu } \mathrm{X}_{\mathrm{o}}^{\mathrm{O}}, \\
& \mathfrak{R}^{\mathrm{O}} \text { - relacja w zbiorze } \mathrm{X}_{\mathrm{o}}^{\mathrm{O}} .
\end{aligned}
$$

Model procesu pomiarowego przedstawiono za pomocą diagramów przekształceń.
Reprezentacja funkcjonalna jest bardzo rozpowszechniona w klasyfikacji systemów pomiarowych.

Poszczególne bloki modelu funkcjonalnego reprezentują wybrane, fizyczne urządzenie, interfejs lub sensor. Nie ma natomiast możliwości uwzględnienia $\mathrm{w}$ tym modelu istotnych dla procesu pomiarowego czynników, takich jak środowisko pomiarowe czy czynnik ludzki, co ogranicza stosowanie modeli funkcjonalnych.

Innym, ważnym aspektem ograniczającym stosowanie funkcjonalnych modeli pomiarowych jest fakt, że służą one do modelowania tylko wybranych, specyficznych typów pomiarów. Powoduje to, że modele takie 
są trudne do uaktualniania lub zastosowania sprawdzonych już rozwiązań w innych systemach pomiarowych.

Modele funkcjonalne posiadają również znaczne ograniczenia $\mathrm{w}$ modelowaniu oddziaływania między poszczególnymi elementami systemu pomiarowego, a w szczególności relacji obiekt pomiaru $\Leftrightarrow$ urządzenie pomiarowe. Powoduje to niekompletny opis systemu pomiarowego, a w konsekwencji niekompletne wyniki pomiarów.

Rzeczywiste systemy pomiarowe pojazdów szynowych charakteryzują się coraz większą złożonością. W strukturze występują podukłady mechaniczne, hydrauliczne, elektryczne układy analogowe i cyfrowe oraz układy mikroprocesorowe. Stosowane sa układy sterowania i regulacji. Badany układ jest układem hybrydowym, to znaczy, że jego działanie ma charakter ciagły w czasie (modelowane za pomocą układu równań różniczkowo-algebraicznych) i dyskretny w czasie (modelowane za pomocą równań różnicowych).

Modelem działania tak złożonego układu jest automat o skończonym zbiorze stanów wewnętrznych, którego przejścia ze stanu do stanu odbywają się według określonej sekwencji lub spowodowane są wystapieniem określonych zdarzeń. W modelowaniu procesu pomiarowego dla układu hybrydowego zastosowano wieloaspektową dekompozycję przyjmując następujące założenia:

(1) w układzie występują różne elementy, między którymi zachodzą określone relacje,

(2) elementy przekazują sobie informacje w określonej postaci,

(3) elementy współpracują ze sobą w określony sposób,

(4) każdy element może znajdować się w różnych stanach,

(5) operacje numeryczne są wykonywane w określonej strukturze informatycznej,

(6) każdy element komuś/czemuś służy.

\section{Obiektowe ujęcie procesu pomiarowego}

Aspekty przedstawione w punkcie 3 zostały sformalizowane za pomocą języka modelowania obiektowego UML (Unified Modeling Language) [1].

Głównymi cechami podejścia obiektowego są:

- enkapsulacja - wydzielenie zewnętrznych aspektów charakteryzujących obiekt, które są udostępniane innym obiektom, od aspektów wewnętrznych, na przykład implementacyjnych,

- dziedziczenie - pozwala na hierarchizację struktury modelu,

- polimorfizm - pozwala na specjalizację poszczególnych aspektów obiektów modelu.

Modelowanie w języku UML polega na graficznej reprezentacji różnych aspektów modelowanego układu za pomocą wybranych typów diagramów. Każdy diagram składa się z węzłów i powiązań między nimi, zwanych krawędziami. Każdy typ diagramu udostępnia własny zestaw węzłów i krawędzi, za pomocą których można modelować poszczególne aspekty systemu.

Diagramy UML dzielą się na diagramy strukturalne, służące do obrazowania statycznych aspektów modelowanego układu:

- diagram klas - klasy, interfejsy i pakiety,

- diagram obiektów - obiekty,

- diagram komponentów - komponenty,

- diagram wdrożenia - węzły,

oraz na diagramy behawioralne, służące do obrazowania dynamicznych aspektów modelowanego układu:

- diagram stanów - zmiany stanów spowodowane zdarzeniami,

- diagram czynności - przepływy sterowania od czynności do czynności,

- diagram sekwencji - kolejność wysyłania komunikatów w czasie,

- diagram kooperacji - struktura obiektów wysyłających i odbierających komunikaty,

- diagram przypadków użycia - scenariusze użycia systemu .

Typy, liczba oraz kolejność diagramów zastosowanych w procesie modelowania systemu zależy od specyfiki tegoż systemu, celów modelowania oraz od punktu widzenia osoby modelującej. Bardzo rzadko zdarza się, by model zawierał diagramy tylko jednego typu lub zawierał wszystkie typy diagramów udostępnianych przez UML.

W kolejnych punktach przedstawiono wszystkie typy diagramów dostepnych w notacji UML. Diagramem wyjściowym modelu jest diagram komponentów, który prezentuje proces pomiarowy pojazdu szynowego. Kolejne diagramy uszczegółowiają wybrane aspekty strukturalne i behawioralne modelu.

\subsection{Diagram komponentów}

Diagramy komponentów prezentują statyczną strukturę modelowanego procesu. Komponenty reprezentują złożone składniki strukturalne modelu i zawierają klasy, interfejsy, typy oraz pakiety. Na zewnątrz komponentów umieszcza się ich publiczne interfejsy służące do komunikacji między komponentami - jeden $\mathrm{z}$ komponentów eksportuje interfejs, a inne go importuja.

W diagramach komponentów wyróżnia się dwa typy powiązań (krawędzie diagramu):

- realizacje - powiązania między komponentami i udostępnianymi przez nie interfejsami,

- zależności - powiązania między dwoma komponentami (bez wyszczególnienia interfejsów, za pomocą których się komunikują) oraz pomiędzy komponentami a interfejsami udostęnianymi przez inne komponenty. 


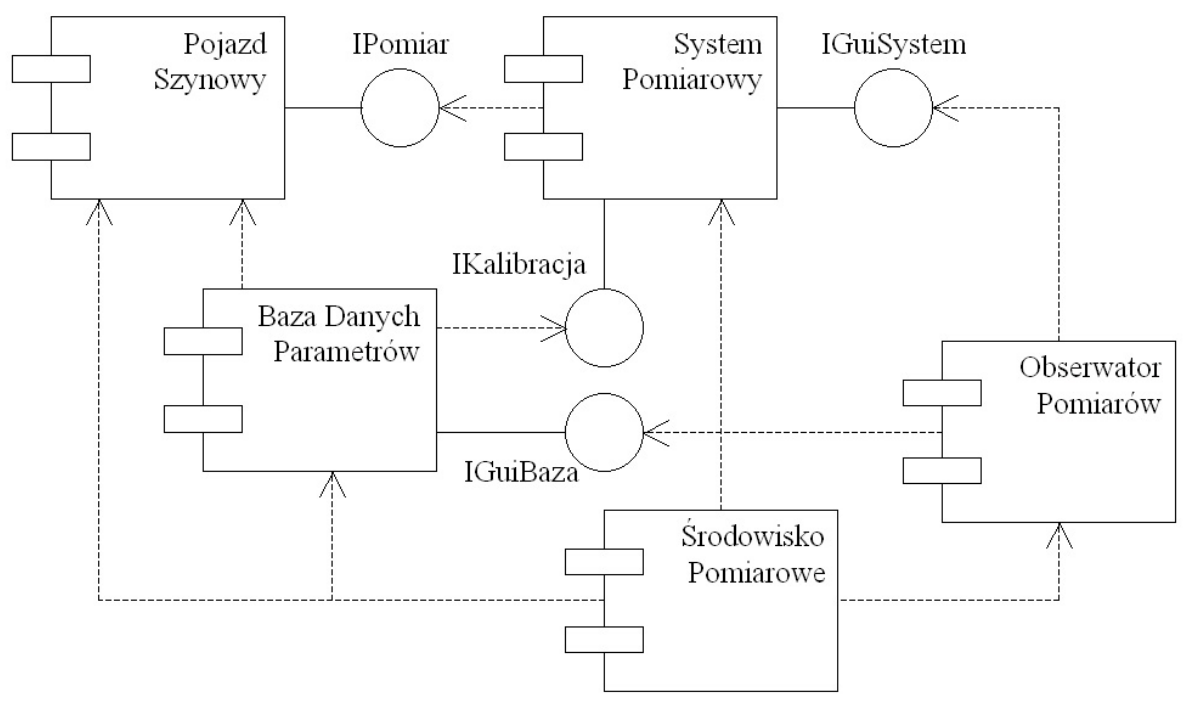

Rys. 2. Diagram komponentów modelu procesu pomiarowego
- klasy, zawierające zarówno atrybuty jak i operacje, będące uogólnieniem fizycznego lub abstrakcyjnego aspektu struktury modelowanego układu,

- interfejsy, definiujące zestaw operacji oferowanych przez klasy i pakiety,

- typy danych, zawierające wyłącznie atrybuty, służące do grupowania danych przekazywanych między klasami,

- pakiety, będące elementami grupującymi dla pozostałych rodzajów węzłów diagramu klas.
Na rys. 2 przedstawiono diagram komponentów modelu procesu pomiarowego. Wyodrębniono pięć komponentów:

- Pojazd Szynowy reprezentujący układ podlegający pomiarom,

- System Pomiarowy interpretowany jako zespół urządzeń biorących udział $\mathrm{w}$ pomiarach, ich przetwarzaniu oraz prezentacji wyników pomiarów,

- Baza Danych Parametrów reprezentujący zbiór danych o wielkościach pomiarowych, zestawy parametrów urządzeń pomiarowych oraz biblioteki procedur pomiarowych,

- Obserwator Pomiarów interpretowany jako osoba (osoby) biorące udział w procesie pomiarowym,

- Środowisko Pomiarowe reprezentujące otoczenie procesu pomiarowego.

Obserwator Pomiarów poprzez interfejs IGuiBaza korzysta z Bazy Danych Parametrów i przygotowuje System Pomiarowy (np. kalibracja czujników pomiarowych, ustawianie filtrów i procedur przetwarzania danych). Następnie, korzystając z interfejsu graficznego IGuiSystem, udostępnianego przez komponent System Pomiarowy, przeprowadza pomiary.

Komponent Pojazd Szynowy udostępnia interfejs IPomiar pozwalający Systemowi Pomiarowemu na odczytywanie wartości wielkości mierzalnych badanego układu.

Środowisko Pomiarowe wprowadza na każdym etapie procesu pomiarowego zakłócenia, co pozwala zamodelować wpływ otoczenia na pozostałe wyodrębnione komponenty.

\subsection{Diagram klas}

Diagramy klas odnoszą się do statycznych aspektów modelu i dlatego zawieraja tylko elementy deklaratywne. Diagramy te pozwalają zaprezentować strukturę modelowanego systemu oraz powiązania wewnątrz struktury. Węzłami diagramów klas są:
Poszczególne węzły diagramów klas mogą znajdować się $\mathrm{w}$ określonych relacjach, zwanych powiązaniami. Rozróżnia się następujące typy powiązań:

- proste - powiązanie, którego znaczenie określane jest poprzez powiązany $\mathrm{z}$ nim opis tekstowy oraz liczebność powiązanych węzłów, może być dwuargumentowe (łączące dwa węzły diagramu) lub wieloargumentowe (łączące trzy lub więcej węzły diagramu),

- $\quad$ dziedziczenie - powiązanie określające mechanizm, dzięki któremu węzły szczegółowe przejmują strukturę i behawioryzm węzłów ogólnych,

- $\quad$ agregacja - powiązanie określające związek typu „całość - część" między węzłem zawierającym oraz węzłem zawieranym,

- $\quad$ kompozycja - szczególny typ agregacji, w którym czas życia węzła zawieranego (składowego) całkowicie zdeterminowany jest przez czas życia agregatu.

Na rys. 3 pokazany został przykładowy diagram klas prezentujący strukturę komponentu Pojazd Szynowy (aby w pełni opisać model procesu pomiarowego należałoby utworzyć diagramy klas dla wszystkich komponentów, jednak wykracza to poza zakres niniejszego artykułu).

Do utworzenia nazw węzłów diagramu zastosowano notację, w której pierwsza litera nazwy identyfikuje rodzaj węzła: litera $\mathrm{C}$ oznacza klasę, litera I oznacza interfejs, litera $\mathrm{T}$ - typ danych, a litera $\mathrm{S}$ - sygnał.

Klasa CPojazdSzynowy reprezentuje fizyczny układ podlegający pomiarom. Może on posiadać dowolną liczbę wielkości, które go opisują (klasa CWielkość). W modelu rozróżnione zostały dwie podklasy wielkości charakteryzujących badany układ - wielkości mierzalne i wielkości niemierzalne, reprezentowane odpowiednio przez klasy CWielkośćMierzalna oraz CWielkośćNieMierzalna, przy czym każda wielkość 


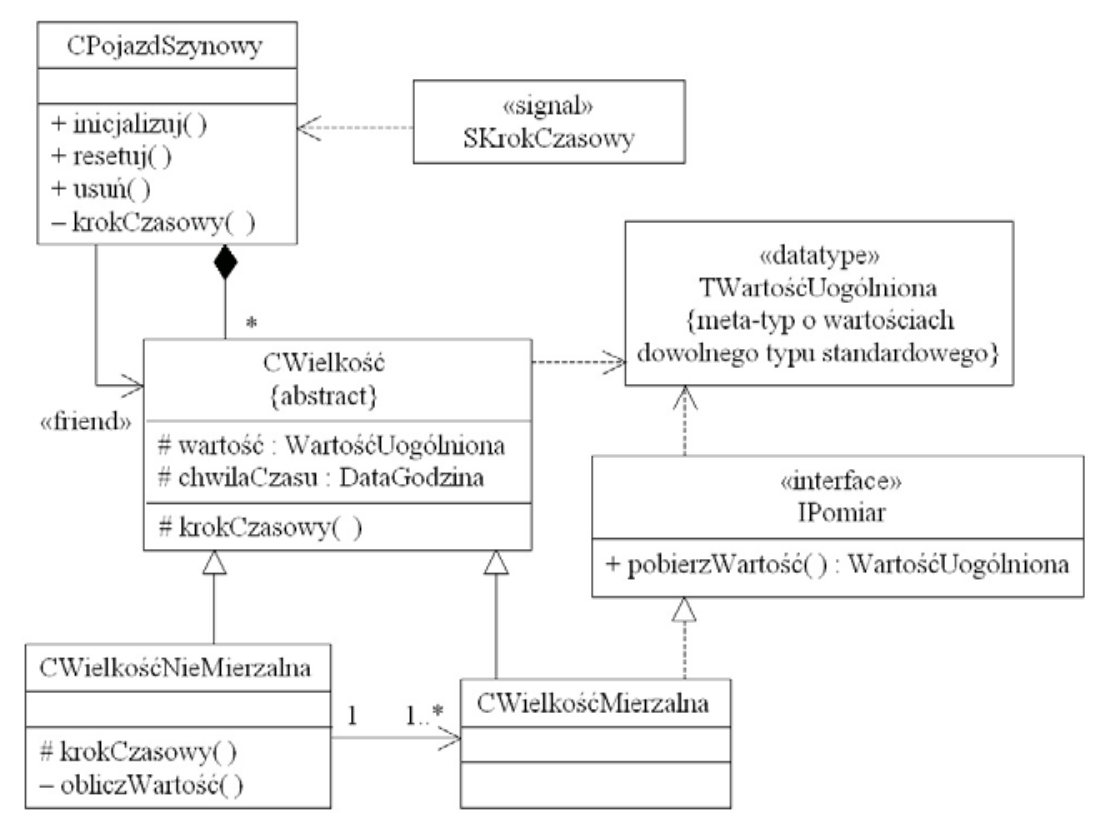

Rys. 3. Diagram klas dla komponentu Pojazd Szynowy
Dla każdej wielkości opisującej badany układ, mierzalnej (reprezentowanej przez obiekty klasy CWielkośćMierzalna) oraz niemierzalnej (reprezentowanej przez obiekty klasy CWielkośćNieMierzalna), wywoływana jest operacja krokCzasowy(), przy czym operacje te sa różne w obu przypadkach. Wartości mierzalne obliczane przez operację 2 : krokCzasowy() liczone są explicite i zależą wyłącznie od wcześniejszych wartości. Wartości niemierzalne wyznaczane przez operację 3 : krokCzasowy() obliczane sa przez operację 3.2 : obliczWartość() na podstawie wartości pobranych przez operacje 3.1 : podajWartość() od wielkości mierzalnych, opisujących daną wielkość niemierzalną. niemierzalna jest opisana przez co najmniej jedną wielkością mierzalną.

Wartości wielkości mierzalnych udostępniane są przez klasę CWielkośćMierzalna za pomocą interfejsu IPomiar, który wykorzystuje typ danych TWartośćUogólniona do przechowywania wartości dowolnych typów danych.

Sygnał SKrokCzasowy służy w modelu do generowania odstępów czasowych, w których wartości wielkości opisujących pojazd szynowy są uaktualniane.

\subsection{Diagram kooperacji}

Diagramy kooperacji dotyczą organizacji obiektów uczestniczących w interakcjach. W węzłach grafu umieszczane są obiekty biorące udział w wymianie komunikatów (nazwy są podkreślone, co oznacza fizyczne wystąpienie obiektu danej klasy), natomiast krawędzie reprezentują powiązania między obiektami uzupełnione o wysyłane/odbierane komunikaty.

W celu przedstawienia komunikatów na osi czasu, oznacza się je kolejnymi liczbami naturalnymi. Do opisu komunikatów zagnieżdżonych stosuje się notację Deweya, która polega na oznaczaniu komunikatów podstawowych kolejnymi liczbami naturalnymi $(1,2$, ...), a komunikaty zagnieżdżone otrzymują kolejne numery poprzedzone numerem komunikatu podstawowego i kropką (np. dla komunikatu oznaczonego 1 są to $1.1,1.2, \ldots)$.

$\mathrm{Na}$ rys. 4 przedstawiony został diagram kooperacji prezentujący proces uaktualniania wartości wielkości opisujących pojazd szynowy. W momencie wystapienia sygnału SKrokCzasowy, pojawiającego się w stałych odstępach czasowych, wywoływana jest operacja 1: krokCzasowy() obiektu klasy CPojazdSzynowy.

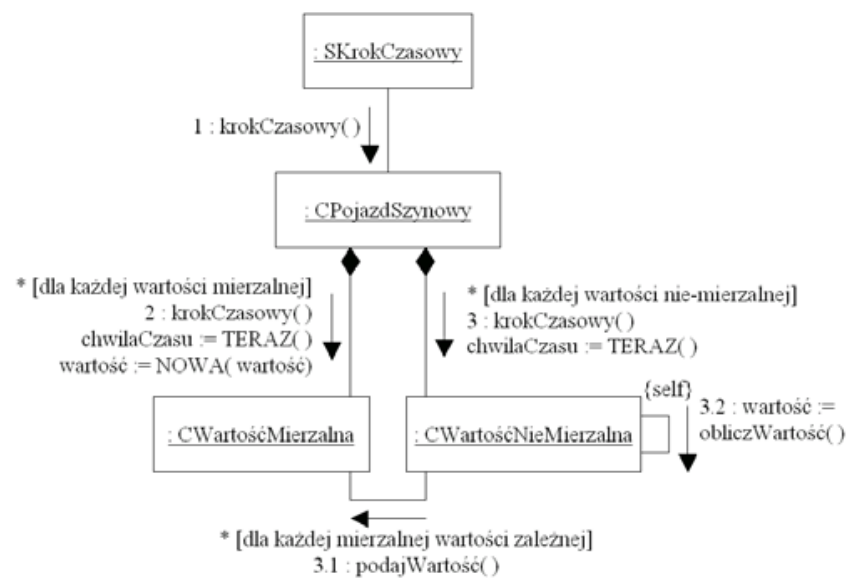

Rys. 4. Diagram kooperacji uaktualniania wartości wielkości opisujących pojazd szynowy

\subsection{Diagram obiektów}

Diagramy obiektów są pochodnymi diagramów klas. Przedstawiają one, dla wybranej chwili, obiekty, będące realizacjami fizycznymi abstrakcji, jakimi są klasy, oraz powiązania między nimi.

Węzłami diagramów obiektów są wyłącznie obiekty, posiadające zdefiniowane wartości dla prezentowanych atrybutów. Powiązania między obiektami nie posiadają oznaczeń kardynalnych (określających liczebność węzłów dla konkretnego powiązania), gdyż każde $\mathrm{z}$ nich występuje między dwoma (lub wieloma, dla powiązań wieloargumentowych) konkretnymi obiektami.

Na rys. 5 przedstawiony został przykładowy diagram obiektów. Prezentuje on strukturę połączeń pomiędzy obiektami komponentu Pojazd Szynowy:

- wielkościami mierzalnymi (obiekty odległość oraz napięcie klasy CWielkośćMierzalna), 


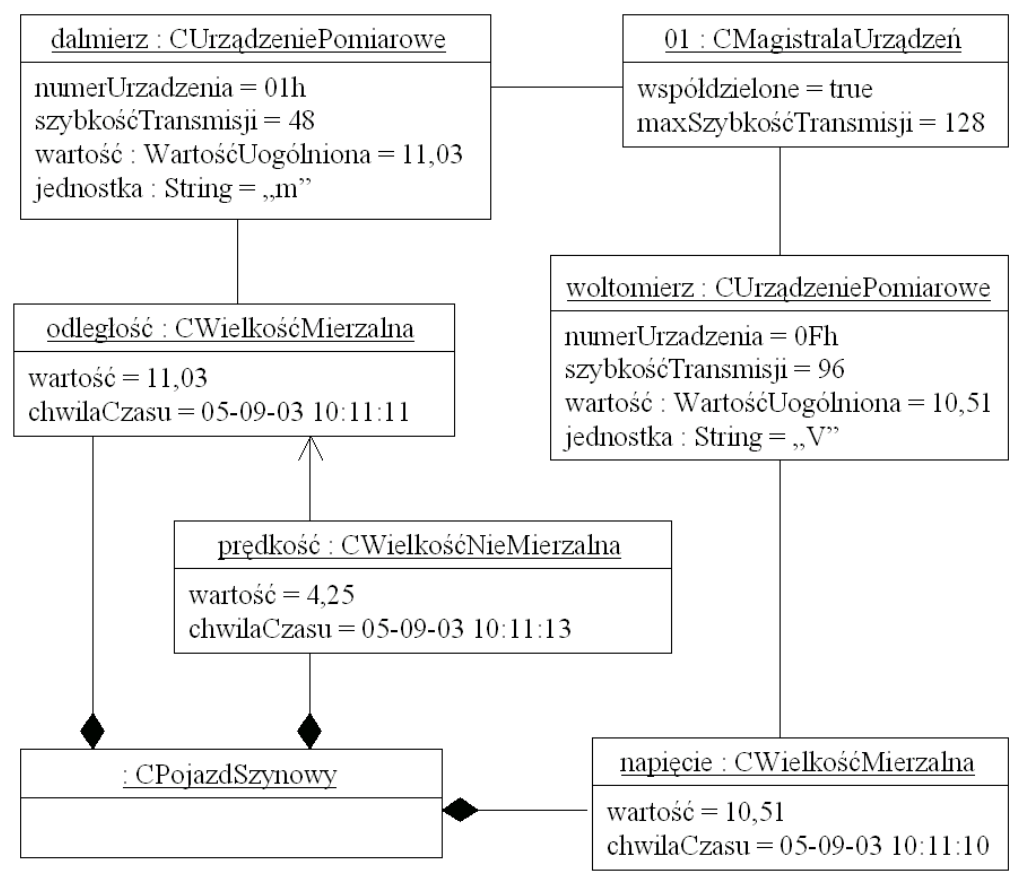

Rys. 5. Diagram obiektów dla wybranych klas modelu

- wielkością niemierzalną (obiekt prędkość klasy CWielkośćNieMierzalna),

- przedmiotem pomiaru (obiekt klasy CPojazd Szynowy),

oraz obiektami komponentu System Pomiarowy:

- magistralą interfejsu urządzeń pomiarowych (obiekt 01 klasy CMagistralaUrzqdzeń),

- urządzeniami pomiarowymi (obiekty dalmierz i woltomierz klasy CUrzqdzeniePomiarowe).

\subsection{Diagram stanów}

Diagramy stanów są podstawowymi diagramami behawioralnymi $\mathrm{w}$ modelu UML. Prezentują one tak zwany cykl życia dla obiektów danej klasy. Zazwyczaj model zawiera tylko kilka diagramów stanów dla obiektów wybranych (ważniejszych) klas.

Każdy diagram stanów posiada stan początkowy (oznaczony wypełnionym, czarnym kółkiem), stany pośrednie (przedstawione jako prostokaty z zaokraglonymi rogami, $\mathrm{z}$ nazwą stanu wpisaną wewnątrz prostokąta) oraz stan końcowy (oznaczony wypełnionym, czarnym kółkiem zawartym w okręgu). W celu poprawienia czytelności diagramu można wyodrębnić tak zwane stany złożone, zawierające kilka stanów zagnieżdżonych.

Przejście obiektu z jednego stanu do drugiego oznaczane jest strzałką. Stan docelowy determinowany jest przez stan, w którym obiekt aktualnie się znajduje oraz zdarzenia zewnętrzne lub/i czasowe.
Na rys. 6 przedstawiony został przykładowo diagram stanów obiektów klasy CMagistralaUrzq̨zeń. Wyodrębnione zostały trzy stany złożone: inicjalizacja, działanie oraz deinicjalizacja, z których każdy posiada jeden lub więcej stanów zagnieżdżonych.

Przejście ze stanu inicjalizacja do stanu działanie następuje, gdy zakończona zostanie inicjalizacja wszystkich urządzeń pomiarowych podłączonych do magistrali. Przejście ze stanu działanie do stanu deinicjalizacja realizowane jest, gdy nastapi koniec wymiany danych poprzez magistralę.

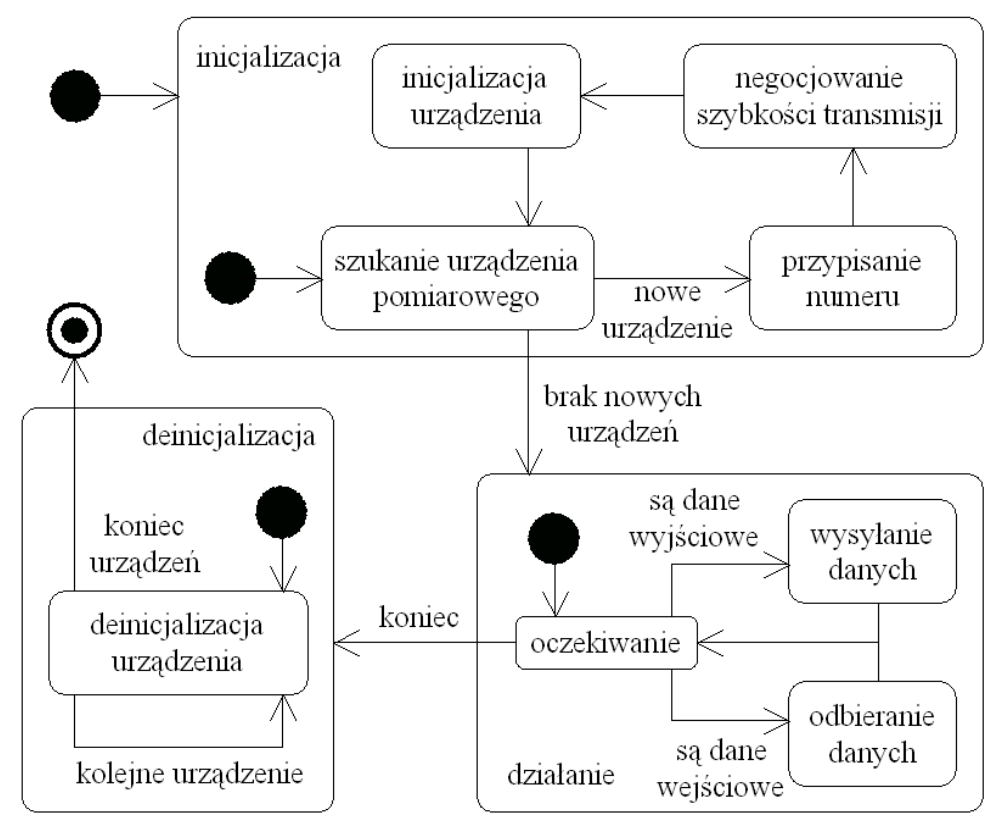

Rys. 6. Diagram stanów obiektów klasy CMagistralaUrzq̨dzeń 


\subsection{Diagram sekwencji}

Diagramy sekwencji służą do przedstawiania komunikatów przekazywanych przez obiekty modelowanego systemu. Charakterystyczną cechą diagramu sekwencji jest oś czasu reprezentowana przez pionowe, przerywane linie biegnące $\mathrm{w}$ dół od każdego obiektu przedstawionego na diagramie. Pozwala to nie tylko na wizualizację obiektów generujących i odbierających komunikaty, ale również na określenie zależności czasowych między poszczególnymi komunikatami.

Na rys. 7 przedstawiony został przykładowy diagram sekwencji. Prezentuje on wymianę komunikatów między obiektami czterech klas: CObserwatorPomiarów (osoba przeprowadzająca badania), CSystemPomiarowy (system pomiarowy), CMagistralaUrzadzeń (magistrala danych systemu pomiarowego) oraz $C U$ rzadzeniePomiarowe (wybrane urządzenie pomiarowe podłączone do magistrali danych). one czynności wykonywanych przez jeden lub więcej obiektów modelowanego systemu oraz przepływ sterowania między tymi czynnościami.

Podobnie jak diagramy stanów, diagramy czynności posiadają stan początkowy i stan końcowy, przy czym stany te dotyczą nie obiektów, ale modelowanych operacji. Przejścia między czynnościami w diagramie są wyłącznie przejściami automatycznymi. Oznacza to, że przejście do następnej czynności w diagramie realizowane jest natychmiast po zakończeniu wcześniejszej czynności.

Oprócz przejść prostych, realizowanych bezwarunkowo od jednej czynności do drugiej, występują również przejścia warunkowe - realizowane jest jedno $z$ dwóch (lub więcej) przejść przy spełnieniu określonego warunku, oraz przejścia współbieżne (rozwidlenia i scalenia) powodujące współbieżne wykonywanie kilku czynności.

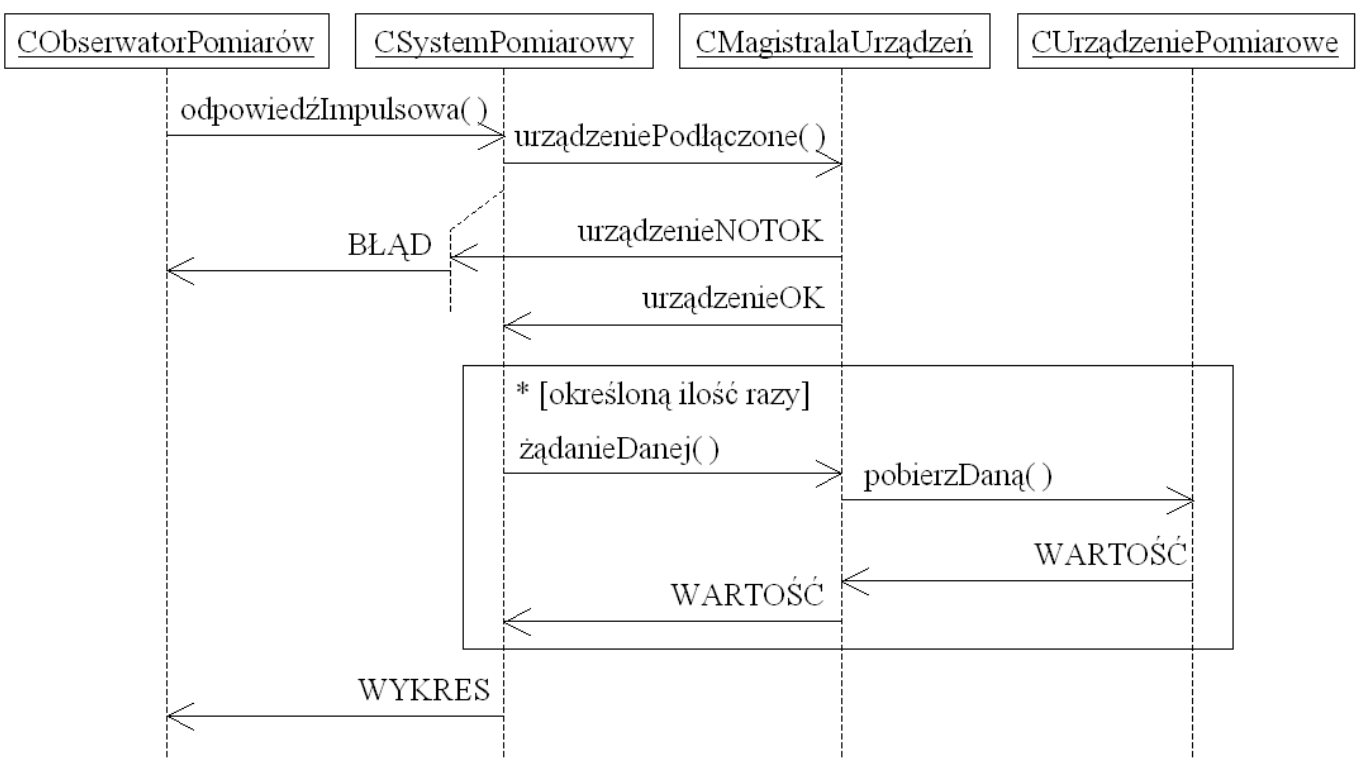

Rys. 7. Diagram sekwencji wyznaczania odpowiedzi impulsowej

Gdy obiekt klasy CObserwatorPomiarów żąda od obiektu klasy CSystemPomiarowy odpowiedzi impulsowej wybranej wielkości mierzalnej badanego ukła$\mathrm{du}$, system pomiarowy upewnia się, czy odpowiednie urządzenie pomiarowe jest podłączone do magistrali. Jeśli nie (odpowiedź urzqdzenieNOTOK), to system pomiarowy przesyła obserwatorowi komunikat o błędzie i sekwencja zostaje zakończona.

Jeśli natomiast urządzenie pomiarowe jest podłączone (odpowiedź urzadzenieOK), to obiekt CSystemPomiarowy pobiera określoną liczbę wartości wielkości mierzalnej od obiektu klasy CUrzqdzeniePomiarowe za pośrednictwem obiektu klasy CMagistralaUrzqdzeń, a następnie prezentuje wykres odpowiedzi impulsowej.

\subsection{Diagram czynności}

Diagramy czynności służą do prezentacji dynamicznych aspektów modelowanego systemu. Zawierają
Na rys. 8 przedstawiony został diagram czynności obrazujący modelowanie zakłóceń występujących w procesie pomiarowym.

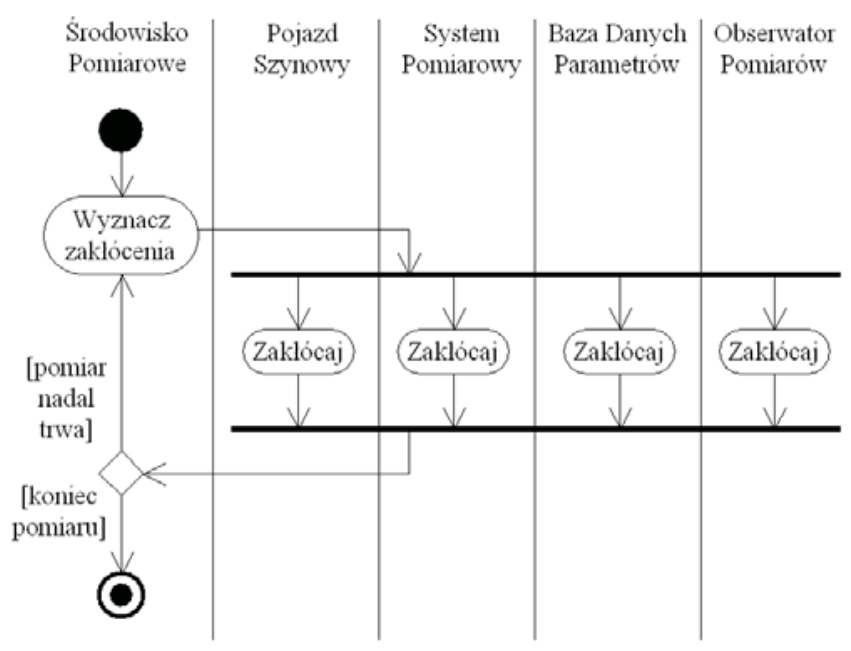

Rys. 8. Diagram czynności związanych z zakłóceniami w modelu 
W momencie rozpoczęcia pomiaru badanego układu, komponent Środowisko Pomiarowe generuje zakłócenia, jakie są przekazane do pozostałych komponentów modelu procesu pomiarowego. Wygenerowane zakłócenia współbieżnie zmieniaja parametry i zachowanie komponentów modelu: Pojazdu Szynowego, Systemu Pomiarowego, Bazy Danych Parametrów oraz $\mathrm{Ob}$ serwatora Pomiarów. Zakłócenia są cyklicznie generowane przez komponent Środowisko Pomiarowe aż do momentu zakończenia pomiarów.

\subsection{Diagram przypadków użycia}

Diagramy przypadków użycia stosuje się do przedstawienia zachowania modelowanego systemu z perspektywy jego użytkowników lub/i zewnętrznych systemów.

Elementy diagramów przypadków użycia nie będące częścią modelowanego systemu nazywane są aktorami i przedstawiane są $\mathrm{w}$ postaci schematycznych ludzików. Modelowany system reprezentowany jest przez prostokąt, w którego wnętrzu znajdują się przypadki użycia (reprezentowane przez elipsy). Poszczególne przypadki użycia wywoływane są przez aktorów, oni również są adresatami rezultatów.

Na rys. 9 przedstawiony jest przykładowy diagram przypadku użycia. Prezentuje on weryfikację kalibracji urządzeń pomiarowych przez użytkownika systemu modelującego proces pomiarowy.

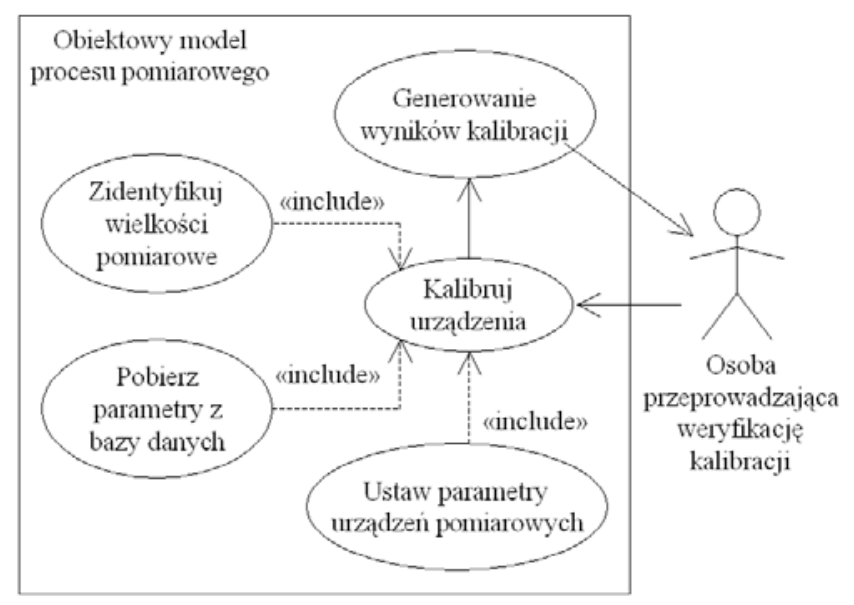

Rys. 9. Diagram przypadku użycia - weryfikacja kalibracji urządzeń pomiarowych

Kalibracja urządzeń wykonywana jest przez użycie Kalibruj urzqdzenia oraz użycia zależne: Zidentyfikuj wielkości pomiarowe, Pobierz parametry z bazy danych oraz Ustaw parametry urzadzeń pomiarowych. Przypadek kończy się działaniem Generowanie wyników kalibracji, które przygotowuje raport z kalibracji urządzeń pomiarowych.

\subsection{Diagram wdrożenia}

Diagramy wdrożenia służą do przedstawienia fizycznej realizacji systemu. Węzły diagramów reprezentują konkretne urządzenia realizujące przydzielone im zadania, a powiązania między węzłami oznaczaja fizyczne połączenia między urządzeniami.

$\mathrm{Na}$ rys. 10 przedstawiony został diagram wdrożenia dla obiektowego modelu procesu pomiarowego. Posiada on dwa węzty:

- stacje roboczq - odpowiedzialną za fizyczną realizację symulacji procesu pomiarowego,

- drukarke - standardowe urządzenie peryferyjne służące do drukowania wyników symulacji.

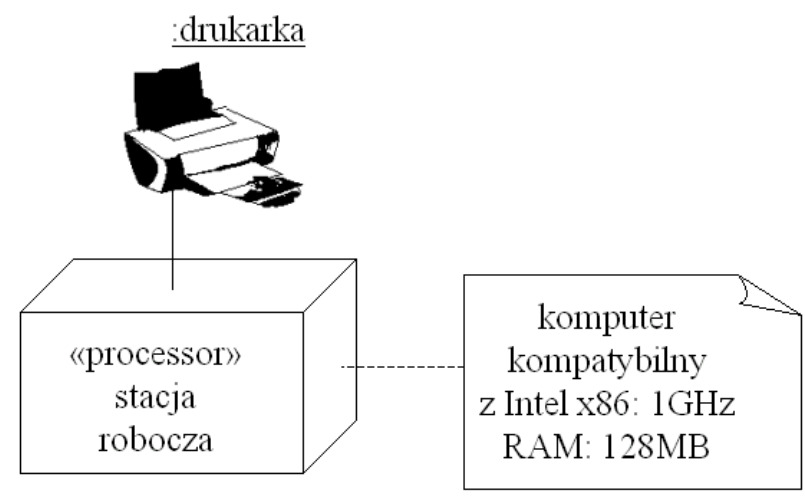

Rys. 10. Diagram wdrożenia dla modelu procesu pomiarowego

$\mathrm{Na}$ diagramie umieszczony został również komentarz, $\mathrm{w}$ postaci schematycznie przedstawionej kartki papie$\mathrm{ru} \mathrm{z}$ zagiętym prawym-górnym rogiem, opisujący podstawowe parametry stacji roboczej.

\section{Podsumowanie}

W artykule przedstawiono zastosowanie różnych formalizmów w modelowaniu procesów pomiarowych:

- model relacyjny,

- model funkcjonalny,

- model obiektowy.

Podkreślono korzyści wynikające $\mathrm{z}$ zastosowania modelu obiektowego $\mathrm{w}$ modelowaniu procesów pomiarowych:

(1) możliwość uwzględnienia hybrydowego charakteru badanych układów,

(2) interdyscyplinarne aspekty związane z czytelną syntaktyką i semantyką języka zorientowanego problemowo,

(3) możliwość bezpośredniego wykorzystania modelu w implementacji informatycznej.

Przedstawiono diagramy UML dla przykładowych elementów modelu procesu pomiarowego.

Rozwój aparatury pomiarowej oraz technik informatycznych umożliwia tworzenie systemów pomiarowych realizujących takie funkcje jak sterowanie pracą 
przyrządów pomiarowych, akwizycje - archiwizację i przetwarzanie danych, zobrazowanie przebiegów pomiarów i stanów wszystkich elementów systemu, wizualizację danych oraz wyników ich przetwarzania i wielu innych. Zastosowanie systemu pomiarowego realizującego tak złożone funkcje do pomiarów złożonego, hybrydowego układu jakim są pojazdy szynowe wymaga przeprowadzenia wnikliwej analizy modelu procesu pomiarowego. W analizie tej wskazane jest zastosowanie podejścia obiektowego $\mathrm{z}$ zastosowaniem UML.

W kolejnym artykule przedstawiony zostanie przykład zastosowania obiektowego podejścia do modelowania procesu pomiarowego $\mathrm{w}$ odniesieniu do działania wybranego funkcjonalnego zespołu pojazdu szynowego.

\section{Literatura}

[1] Alhir S. S., UML. Wprowadzenie, HELION, Gliwice, 2004

[2] Mari L., Epistemology of measurement, Measurement, Vol. 34, 2003

[3] Nawrocki W., Komputerowe systemy pomiarowe, Wydawnictwo Komunikacji i Łaczności, Warszawa, 2002

[4] Subramanian N., Using object-oriented technology to design efficient IEEE-488.2 (GPIB) interface instruments, Computer Standards \& Interfaces, Vol. 22, 2000

[5] Urbański M., Samsonowicz J., On the field nature of measuring process, Measurement, Vol. 34, 2003

[6] Yang Q., An Object-Oriented Model of Measurement Systems, IEEE Transaction on Instrumentation and Measurement, Vol. 47, 1998 